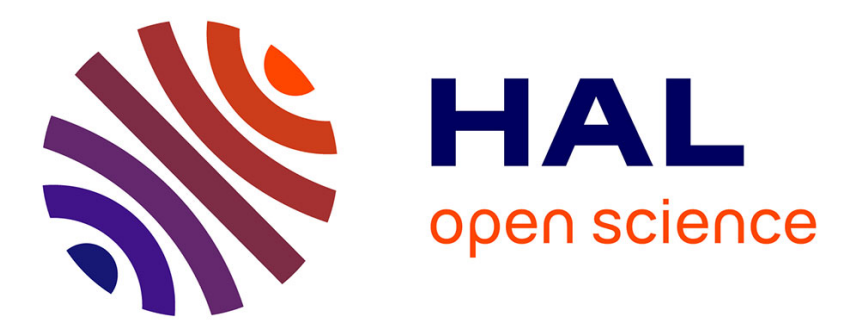

\title{
Making decisions on industrial water sources: the case of Zaragoza, Spain
}

Fernando Arbués, María A. García-Valiñas, Inmaculada Villanúa

\section{To cite this version:}

Fernando Arbués, María A. García-Valiñas, Inmaculada Villanúa. Making decisions on industrial water sources: the case of Zaragoza, Spain. Urban Water Journal, 2020, 17 (2), pp.122-135. 10.1080/1573062X.2020.1748207 . hal-03191503

\section{HAL Id: hal-03191503 \\ https://hal.univ-reunion.fr/hal-03191503}

Submitted on 7 Apr 2021

HAL is a multi-disciplinary open access archive for the deposit and dissemination of scientific research documents, whether they are published or not. The documents may come from teaching and research institutions in France or abroad, or from public or private research centers.
L'archive ouverte pluridisciplinaire HAL, est destinée au dépôt et à la diffusion de documents scientifiques de niveau recherche, publiés ou non, émanant des établissements d'enseignement et de recherche français ou étrangers, des laboratoires publics ou privés. 
Title: Making decisions on industrial water sources: The case of Zaragoza, Spain Authors:

Fernando Arbués (corresponding author)

Aragon Public Economics Research Group

Institute of Environmental Science (IUCA)

University of Zaragoza

Violante de Hungría 23

50009 Zaragoza (Spain)

e-mail: farbues@unizar.es

Mã Ángeles García-Valiñas

Oviedo Efficiency Group

Department of Economics

University of Oviedo

Avda. del Cristo $\mathrm{s} / \mathrm{n}$

33006 Oviedo (Spain)

e-mail: mariangv@uniovi.es

Inmaculada Villanúa

Aragon Growth, Demand and Natural Resources Research Group

University of Zaragoza

Gran Vía, 2

50005 Zaragoza (Spain)

e-mail:villanua@unizar.es 


\section{Abstract}

In Southern Europe numerous areas suffer water scarcity. For public policies to be effective, a thorough study of water users must be conducted. This paper aims to analyse the key factors that influence the decision of industrial users in urban areas when choosing between withdrawing water from underground sources or using water supplied through the public network. Using a database of industrial firms in Zaragoza (Spain) the proportion of water drawn from wells is considered as the dependent variable of a fractional response model. This methodology provides an original contribution to the field of behavioural analysis of the industrial sector, enabling us to model industrial decisions on water sources. The results obtained show that the most significant decision-drivers are how the industries use the water, the firms' location and the accessibility of the different sources. Moreover, the findings indicate that firms use lower proportions of well water during the summer.

\section{Keywords}

Fractional response models, industrial water use, water source, well, public network. 
Making decisions on industrial water sources: The case of Zaragoza (Spain)

\section{Introduction}

Currently, approximately one-third of European Union (EU) territory is subject to water stress (EEA 2018a). According to the European Environmental Agency (EEA) climate change is heating up in Europe (EEA, 2017), so in the coming years a significant rise in temperatures as well as a drop in rainfall is expected (EEA, 2019a). The impacts of climate change are especially intense in South-Eastern and Southern Europe, where about $50 \%$ of this area suffers from water scarcity, particularly during the spring and summer seasons (EEA 2017; 2019b). On the other hand, the demand for water for various uses will continue to rise, increasing the pressure on water bodies in South-Eastern and Southern European regions (EEA, 2017, 2019b; Ritchie and Roser, 2020). Moreover, changes in weather patterns combined with the growing demand for water are leading to a significant deterioration of water resources in terms of quality (pollution and eutrophication) and quantity (drought, overexploitation of aquifers, etc.) in these European regions (EEA, 2019c; Ibisch et al., 2016; Jeuken et al., 2017; Padedda et al., 2017). In this general context, Spain has been categorized as the driest of the semi-arid EU member states, frequently affected by drought and water scarcity (Lopez-Gunn et al., 2012; Vargas and Paneque, 2019; Versini et al., 2016).

Furthermore, the limitation of "supply-side" infrastructure (i.e. big dams) developed over past decades to meet water demands emerges as a key issue for water managers in most urban areas. In spite of significant investments in reservoirs and new water supply infrastructures, in several urban areas water authorities are unable to provide adequate water services (Flörke et al., 2018; Krueger et al., 2019). In view of the gravity of the problem and its global scale, the EU, within the framework of its Europe 2020 Strategy (European Council, 2011), has emphasized the importance of the demand management approach. In this respect, it recommends combining the use of water prices or other economic instruments with tools that are not strictly economic (EEA, 2018c). For these measures to be effective, several water users demand (households, agriculture and industry) must be characterized, along with the determinants of that demand. This will help the managers of public water supply networks to design the policy alternative that is best suited to each group of users. 
Recent reports have shown that industrial water sourced from the public water supply in Spain accounts for $14.77 \%$ of total water use for all economic activities (EUROSTAT 2019a) ${ }^{1}$. Furthermore, EUROSTAT (2019b) shows that in Spain, self-supplied water (that is, direct water withdrawn by the user from a groundwater or surface-water source) and water from sources other than the traditional public water supply sources (i.e., desalination of brackish or saltwater; reuse of urban/industrial wastewater) are found to be the main water source for the manufacturing industry (about $64.86 \%$ of water used in the manufacturing industry). In addition, it is important to indicate that the industrial sector is considered one of the worst polluters of water bodies in Spain (European Commission, 2014).

Focusing on Spain, Zaragoza is a city located along the banks of the river Ebro. As Lutz and Merz (2016) indicate, water resources in the River Ebro Basin are currently under pressure due to several factors such as industrial activities, agriculture or urban water abstraction. Additionally, several climate studies point out that the Ebro River Basin has become hotter and drier (Bovolo et al., 2010), with longer and more intense drought episodes (Bovolo et al., 2010). Under these water scarcity conditions, climate change can amplify the impact of these factors in terms of quantity and quality (Bovolo et al., 2010; Lutz and Mez, 2016; Omedas et al., 2011). Moreover, the Ebro River Basin, with 108 big dams, is one of the most regulated river basins in Europe, so the ability to manage growing water demands by building new infrastructures is very limited (Omedas et al., 2011).

In this context, this research is aimed at analysing industrial water use in urban areas. In particular, we are interested in exploring the specific features that characterize industrial users. Frequently, firms are able to take water from alternative sources such as the public network or private wells (Sengupta 2018). Our main contribution consists of identifying the key drivers of this decision. Using a database of manufacturing firms in Zaragoza (Spain, Southern Europe), we estimate an empirical model where the dependent variable is the proportion of water taken from wells.

The econometric approach is based on fractional response models, commonly applied in finance and accounting research (among others: Czarnitzki and Kraft 2004; Kang and Nanda 2018; Loudermilk 2007) as well as in other contexts such as agricultural economics (Villoria and Liu 2018), labour economics (Fatima and Khan 2019; Kölling 2018) or international economics

\footnotetext{
${ }^{1}$ In most EU countries (current exceptions are England, Wales, and the Czech Republic), network and other water infrastructures' ownership remains in public hands, even if water services management is externalized to a private company.
} 
(Eickelpasch and Vogel 2011; Fakih and Ghazalian 2014; Wagner 2003). In the field of water economics, there are some studies that use logit fractional models. Nauges and Strand (2017) analyse the relationship between water hauling and girls' school attendance, while MartínezEspiñeira, García-Rubio and González-Gómez (2017) study the quality of urban water networks. However, as far as we know, this methodology has not been applied to characterize industrial water use.

This study is structured as follows. Section 2 describes the socioeconomic and hydrogeological context, addressing the industrial sector and the main water sources in Zaragoza. Section 3 is focused on the econometric modelling used in the empirical approach. Section 4 presents the database and variables. Section 5 details the main results. Section 6 includes a discussion of the results. Finally, we conclude with a brief discussion on policy implications and future challenges.

\section{Case study}

Zaragoza is the biggest city in the central area of the Ebro River Basin (North-Eastern Spain). It is the fifth largest city in Spain with 666,880 inhabitants (INE 2018a). This municipality is located in the centre of the tertiary depression of the Ebro, at the intersection with two of this river's tributaries: The Huerva and the Gállego rivers. According to INE (2018b), the municipality has a surface area of $972.26 \mathrm{~km}^{2}$. That area is split among urban uses $\left(155.95 \mathrm{~km}^{2}\right.$; $16.04 \%$ of the territory) agricultural uses (30.47\%) and natural areas (mostly grassland, shrubland and bare land) surrounding the city (53.49\%).

As shown in Table 1, urban land uses in Zaragoza are quite evenly distributed. Residential use accounts for the largest surface area, occupying $25.87 \%$ of the total urban area, while $23.13 \%\left(36.07 \mathrm{~km}^{2}\right)$ is devoted to services and industrial activities. Infrastructure represents $22.51 \%$ of total urban land use, while other uses (construction areas, municipal dumps, etc.) amount to $22.32 \%$. Finally, urban green areas (parks, public gardens, etc.) account for only $6.17 \%$ of the total. 
Table 1. Urban land use in Zaragoza (2017)

\begin{tabular}{ll}
\hline Land use & Surface (\%) \\
\hline Residential use & 25.87 \\
Economic activities & 23.13 \\
Infrastructure & 22.51 \\
Urban green areas & 6.17 \\
Other & 22.32 \\
\hline
\end{tabular}

Source: INE (2018b)

Moreover, $92.11 \%$ of the area devoted to economic activities $\left(33.22 \mathrm{~km}^{2}\right)$ is occupied by industrial estates (IAF 2019; Zaragoza Chamber of Commerce and Industry 2019). There are 40 such estates registered in the Zaragoza municipality (IAF, 2019; Zaragoza Chamber of Commerce and Industry, 2019), and most of them (30 industrial estates; $30.78 \mathrm{~km}^{2}$ ) are located in the outskirts of the city, in the areas surrounding the airport, and close to the main roads connecting the city with other major Spanish cities (Madrid, Barcelona, Bilbao Valencia). The remaining industrial estates are within the city centre next to residential districts, but they cover a very small area $\left(2.44 \mathrm{~km}^{2}\right)$ and primarily contain small and medium-size enterprises. The companies develop their activities in a wide range of sectors, with metal manufacturing, wholesale and logistic services being the most relevant. Furthermore, other important economic activities are machinery and equipment manufacturing, electric and electronic product manufacturing, plastic and rubber manufacturing and the manufacture of food products. Thus, Zaragoza is a major industrial area, with 2,040 companies listed on the City Council register in 2015 (INE, 2018c) and with an intensive industrial activity (INE 2018b, 2018c).

With respect to water management, it is worth noting some specific features. In Zaragoza, urban water services have not been outsourced to the private sector, so they are publicly owned and operated. Therefore, the City Council directly manages public water services in the municipality. To operate in the municipal area, all the industrial activities are required to be connected to the public water network. In addition, the Spanish Water Act (BOE, 2001) establishes that the State, through the actions of Basin Authorities, is responsible for groundwater management. The Law states that well owners can obtain an administrative concession to draw a maximum amount of water from underground sources, which grants 
them a "temporary private property" status for a maximum period of 75 years (Fornés et al., 2007). Furthermore, the River Basin Authority is the responsible for ensuring the volume of pumped groundwater does not exceed the maximum cap authorized in the concession. Thus, according to CHE (2019a), there are 143 wells for industrial uses registered in the municipal area of Zaragoza. Direct withdrawals from a surface water source (rivers, waterways, lakes...) also are feasible subject to previous approval by the River Basin Authority (BOE, 2001). As we will describe below, this option is mostly used by agricultural users and urban systems ${ }^{2}$.

When water is obtained from the urban water distribution system there are two charges: supply and sewage/sanitation services (Appendix I contains a detailed description of Zaragoza water tariffs in the period analysed)., However, when water is obtained from the aquifer industries are only charged for the sewage/sanitation service. Since firms using underground water do have to cover the cost of drilling and pumping water from the aquifers, the infrastructures to withdraw water from underground sources are privately owned and operated.

From a hydrological perspective, Zaragoza is located over two important groundwater bodies: the alluvial aquifers of the Ebro and the Gállego. These water bodies are linked to both river flows, forming a single hydrological unit (Moreno et al. 2008). Figure 1 shows the aquifer structure and its location in the Zaragoza city area. The steady growth of the city in the last 40 years has led to more land being dedicated to residential use. Consequently, economic activities have been pushed out to peripheral areas of the city located on the left bank of the Ebro River and over the alluvial aquifer of the Gállego. This process of urban growth and restructuring jeopardizes the quality and availability of water in those aquifers (CHE, 2008; CHE, 2015; García-Gil et al., 2014; Moreno et al., 2008).

\footnotetext{
${ }^{2}$ There is only one administrative concession to withdraw water from surface bodies (Ebro River) in the municipality of Zaragoza. This company is located in a meander of the river and it is authorised to extract a quantity of water, which would prove impossible to be extracted from a well $(3,722,976$ $\left.\mathrm{m}^{3} / \mathrm{month}\right)$.
} 


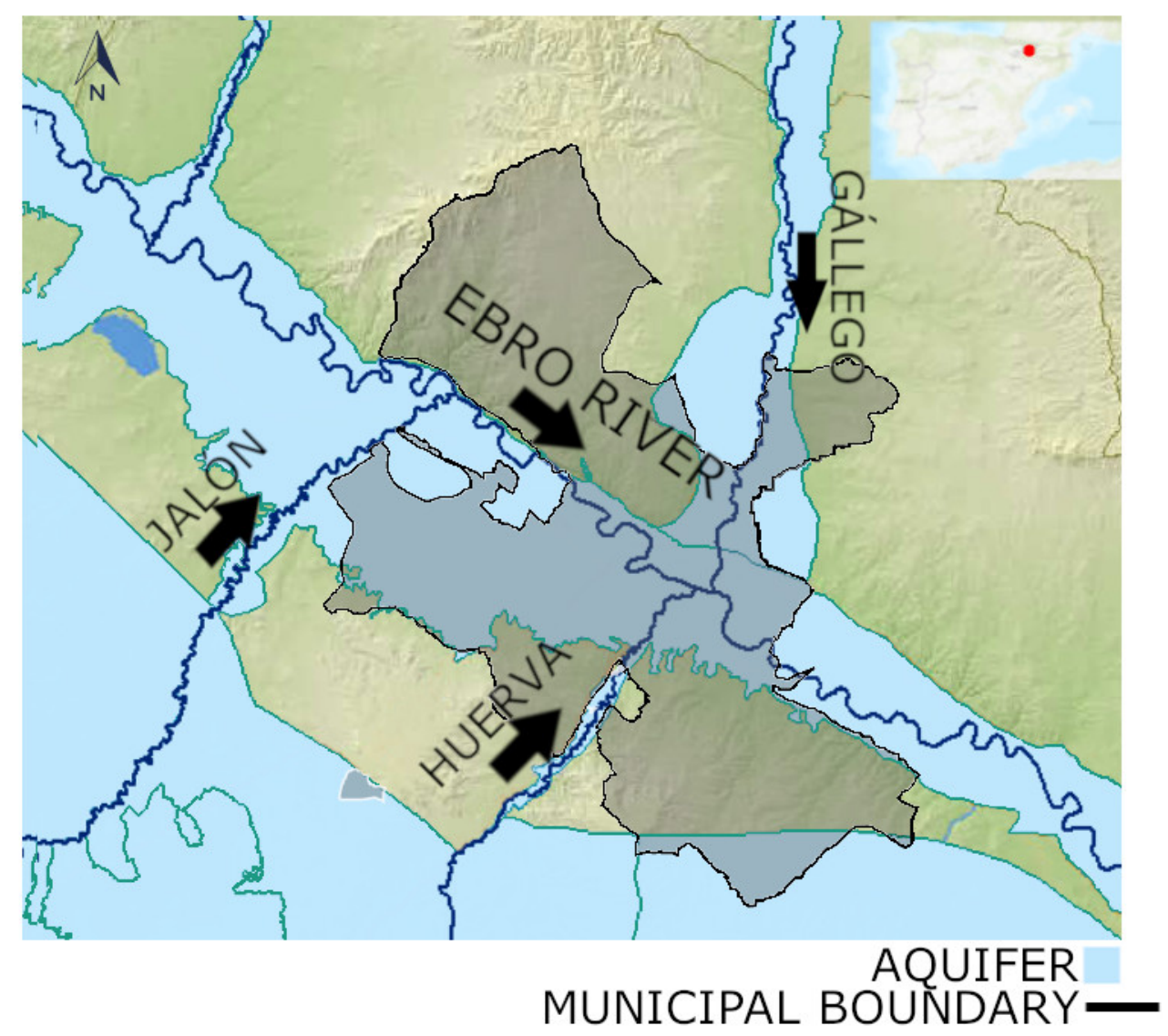

Source: Own elaboration from MAPAMA (2019)

According to Moreno et al. (2008), drilling and tube wells are the most frequently-used systems for exploiting groundwater in Zaragoza, with electrical submersible pumps being the most widely used technology. Well depth varies significatively (between $3.35 \mathrm{~m}$ and $92 \mathrm{~m}$ according to IGME, 2020), depending on the level of the alluvial terrace where the drilling takes place (the higher the terrace, the greater the depth of the well) how close the water table is to the surface (Moreno et al. 2008). As mentioned above, the aquifers are largely in the city outskirts, where most of the industrial parks are located.

Although in Spain groundwater is mostly used by the agricultural sector $169.33 \%$ of total extractions, according to INE, 2016), the level of industrial use is quite significant in the municipal area of Zaragoza, accounting for $76.2 \%$ of total extractions from the aquifer, while 
recreational uses and irrigation account for $9.89 \%$ and $13.91 \%$ respectively (Garrido et al., 2014). Urban water suppliers and irrigators have little incentives to exploit groundwater sources due to how relatively easy is to take water from the Ebro River and the high treatment costs required to improve the quality of the groundwater (CHE, 2008; CHE, 2015). The Ebro River is one of the biggest in the Iberian Peninsula, $930 \mathrm{~km}$ in length and an average discharge of 426 m3/s. According to CHE (2015), in the Ebro River Basin $96.69 \%$ of water for agricultural uses and $91.94 \%$ of water for urban water supplies is drawn from surface water bodies. For industrial activities, only $56.49 \%$ of water is directly taken from surface sources (water taken from the public network is not included in this figure).

Conversely, as Garrido et al. (2014) show, the withdrawals from the aquifer by industrial users (mainly for refrigeration activities) are increasing in recent years because some industries require high volumes of water. Furthermore, for some industrial uses the water does not need to be of very high quality (e.g., for cleaning installations or extinguishing fires). As such, and given their proximity to the aquifer, using groundwater is an attractive option for industrial firms. This alternative can also be cheaper than water taken from the public network, and it ensures an uninterrupted water supply when problems occur with the public network (pipeline damage, loss of pressure, etc.).

\section{Econometric model}

We aim to identify the factors that affect the firms' decision regarding their source of water supply. Depending on which factors are important in explaining the water source choice, the results obtained could have implications for the effectiveness of water policies. Furthermore, the information obtained would be useful in designing measures based on the characteristics of companies in order to improve the efficiency in water consumption.

To this end, we propose a fractional response non-linear model where dependent variable represents the proportion of well/network water used by industrial firms. When the dependent variable is a fractional response variable, the specified model and the estimation method are usually different from the classical linear model. In order to justify this difference, and following Papke and Wooldridge (2008), several reasons can be argued. First, a linear functional form might miss important nonlinearities. Additionally, even when holding a linear form, this model doesn't guarantee a predicted value into the unit interval, which is the range of our dependent variable. Moreover, when developing a log-transformation, the model fails for responses at the corners, zero and one. Further, this transformation does not allows 
recover the expected value of the original fractional variable, excepting strong independence assumption.

Once we have justified that linear models are not adequate when aiming to explain a fractional response variable, we can also affirm that it cannot be modelled using a binary response model because the dependent variable it is a proportion, so it is a continuous variable that takes any value in the interval $(0,1)$.

Fractional response models were introduced by Papke and Wooldridge $(1996,2008)$. They have since been developed and used by several authors, such as Baum (2008), Bluhm (2013), Williams (2016) and Wooldridge (2011). ${ }^{3}$ These models also enable an analysis of cases with more than two weights (Koch, 2010). Nevertheless, and as we mentioned before, our study focuses on two proportions (well/network).

In order to estimate fractional probit models, we have two alternative estimation procedures, described in Papke and Wooldridge (2008): the pooled Bernoulli quasi Maximum Likelihood estimation (QML); and the generalized estimating equation (GEE) applied to panel data (Liang and Zeger 1986).

First, we focus on the QML method, which is also called pooled fractional probit (PFP). Let $w_{i t}$ be the variable which represents the proportion of well water consumption, versus network water, and $\mathbf{x}_{\mathbf{i t}}$ a $1 \times \mathrm{k}$ vector, including the potential factors that can have an impact on $w_{i t}$ for firm $\mathrm{i}$ in a time period t. We first assume:

$$
E\left(w_{i t} \mid \mathbf{x}_{\mathbf{i t}}, c_{i}\right)=\Phi\left(\mathbf{x}_{\mathbf{i t}}^{\prime} \boldsymbol{\beta}+c_{i}\right)
$$

where $\Phi$ denotes the standard normal cumulative distribution function (cdf), $\boldsymbol{\beta}$ is the corresponding parameter vector, and $c_{i}$ are the unobserved effects. Expression (1) corresponds to a fractional probit model. Although it is not a binary model, the PFP method estimates the parameter vector by maximizing the likelihood function, which can be written as:

$$
L=\left(\Phi(\cdot)^{w_{i t}}(1-\Phi(\cdot))^{1-w_{i t}}\right)
$$

As Papke and Wooldridge (2008) establish, under the normality assumption for $\mathcal{C}_{i}$, we can write $c_{i}=\psi+\overline{\mathbf{x}}_{\mathbf{i}} \xi+a_{i}$, where $a_{i} \sim \operatorname{Normal}\left(0, \sigma_{a}^{2}\right)$, and $\overline{\mathbf{x}}_{\mathbf{i}}$ is a vector including the average of the time-varying variables of $\mathbf{x}_{\mathbf{i} t}$. As the authors advise, the average of the time-period

\footnotetext{
${ }^{3}$ These studies develop the theoretical framework of fractional response models and their empirical application. Moreover, some of them provide the Stata commands to carry out the applications.
} 
dummies should not be included in $\overline{\mathbf{x}}_{\mathbf{i}}$. Taking into account the normal distribution of $c_{i}$, we can write the expected fractional variable as:

$$
E\left(w_{i t} \mid \mathbf{x}_{\mathbf{i}}\right)=\Phi\left(\alpha+\mathbf{x}_{\mathbf{i t}}^{\prime} \boldsymbol{\beta}_{\mathbf{a}}+\overline{\mathbf{x}}_{\mathbf{i}}^{\prime} \boldsymbol{\gamma}\right)
$$

The parameters of the model are $\alpha, \boldsymbol{\beta}_{\mathrm{a}}$ and $\boldsymbol{\gamma}^{4}$. Nevertheless, we focus on the interpretation of $\boldsymbol{\beta}_{\mathrm{a}}$ which, as in (1), corresponds to the parameters of every explanatory factor. The sign of every element of the parameters vector gives information about the direction of the change in the proportion of well water consumption under changes in the corresponding regressor. Thus, if the explanatory factor increases, a sign positive of the corresponding parameter implies that the proportion of well water use also increases. In the opposite side, a negative sign of the parameter means that the well water proportion decreases when the factor increases.

As in binary probit models, it can be assumed that the variance of $w_{i t}$ has the following expression:

$$
\operatorname{Var}\left(\mathrm{w}_{i t}\right)=\sigma^{2} \Phi(\cdot)(1-\Phi(\cdot))
$$

where the argument of $\Phi$ is the same as in expression (3). The QML estimator takes into account this variance. Nevertheless, we use the "cluster" option in Stata, in order to get standard errors and test statistics that are robust to both serial dependence across $t$ and violations of equation (4).

In this paper we also extend this procedure, which was developed by Papke and Wooldridge (2008) in the framework of a balanced probit model, to a fractional logit response model expressed as follows:

$$
E\left(w_{i t} \mid \mathbf{x}_{\mathbf{i}}\right)=\Lambda\left(\alpha+\mathbf{x}_{\mathbf{i t}}^{\prime} \boldsymbol{\beta}_{\mathbf{a}}+\overline{\mathbf{x}}_{\mathbf{i}}^{\prime} \gamma\right)
$$

where $\Lambda(\cdot)=\exp (\cdot)(1+\exp (\cdot))^{-1}$.

We now focus on the GEE method to estimate the parameter vector of our fractional model. GEE estimation allows for different kinds of serial correlation and a misspecified conditional variance. We must specify a "working correlation matrix". The most common one assumes correlations that are not a function of the regressors in $\mathbf{x}_{\mathbf{i}}$, which is called an "exchangeable" correlation pattern. If we define the errors $u_{\mathbf{i}}=w_{i t}-E\left(w_{i t} \mid \mathbf{x}_{\mathbf{i}}\right)$, the

\footnotetext{
${ }^{4} \mathrm{QML}$ procedure is implemented in Stata through the generalized linear model (GLM) command fraglm (Williams, 2018).
} 
standardized errors will be $e_{i t}=u_{i t} / \sqrt{\Phi(\cdot)(1-\Phi(\cdot))}$ if the fractional is probit. Then, the exchangeable correlation matrix assumes that $\rho$ is the constant correlation coefficient between pairs of standardized errors. Like the QLM estimation method, in GEE procedure the standard errors are robust to general heteroscedasticity and serial correlation. GEE estimation produces valid standard errors even if correlations within group are not that assumed in the specified correlation pattern (in our case "exchangeable").

As in any non-linear model, the parameters of models (1) and (6) do not represent the marginal (partial) effects of regressors on the dependent variable. When interpreting the estimated model, the calculation of these marginal effects is a key issue (Greene and Hensher 2010; Wooldridge, 2002). The sign of the parameters provides the direction of the change in the proportion of well water use under changes in a specific regressor but not its magnitude (the partial effect) is not given by the value of the parameter. In order to obtain this quantity, the partial effect must be calculated. We have both continuous and discrete regressors, and the way of obtaining the marginal change is different depending on the type of variable. For a continuous variable, $X_{j}$ the marginal effect is obtained as follows:

$$
\frac{\partial E\left(w_{i t} \mid \mathbf{x}_{\mathbf{i t}}, c\right)}{\partial X_{j i t}}=\beta_{j} f(\cdot)
$$

where $f(\cdot)$ is the normal or logistic density function, depending on the estimated model (probit or logit). If $X_{j}$ is a dummy, we compute the difference between the cumulative distribution function ( $\Phi$ or $\Lambda$ ) when it takes a value of 1 and when it has zero value, holding the remaining regressors constant. The average partial effect (APE) is obtained as the mean of the marginal effects of all observations. The analysis of both the sign of the estimated coefficients and the magnitude of the partial (marginal) effects allows the researchers and politicians to know how every factor influence on the decision of using the two water sources.

\section{Database and variables}

To carry out the empirical analysis, we have built a balanced panel data set of 39 firms located in Zaragoza, with observations for 12 quarters over the period 2004-2006. All of the firms included in the sample are officially registered as well users at the City Council and have access to the public water network. The construction of a database of these characteristics is a significant contribution of this research paper. Moreover, this is the first applied study in the 
field using a fractional response model. As mentioned above, the dependent variable (pwell) represents the proportion of consumed water sourced from a well. The factors that can potentially influence the use of well/network water have been selected according to the previous literature about industrial water demand (Arbués et al., 2010; Rees, 1969; Renzetti, 1993; Reynaud 2003). These variables are briefly described in Table 2.

Table 2. Independent variables

\begin{tabular}{|c|c|c|}
\hline Name & Description (units) & Source \\
\hline KI & $\begin{array}{l}\text { Ratio: Value of the firm's assets } \\
\text { /number of workers ( } € \text { million } \\
\text { per worker) }\end{array}$ & SABI database \\
\hline Pollut & $\begin{array}{l}\text { Pollution index (variable ranging } \\
\text { from } 1 \text { to } 1.3 \text { ) }\end{array}$ & Zaragoza City Council \\
\hline Product & $\begin{array}{l}=1 \text { if water is used to produce } \\
\text { the end product; } 0 \text { otherwise }\end{array}$ & Zaragoza City Council \\
\hline Msize & Diameter of the meter (mm.) & Zaragoza City Council \\
\hline Depth & Well depth (m.) & $\begin{array}{l}\text { Ebro River Basin Authority (CHE } \\
\text { 2019a) }\end{array}$ \\
\hline Distance & Distance to city centre $(\mathrm{km})$. & $\begin{array}{l}\text { IAF (2019) and Zaragoza Chamber of } \\
\text { Commerce and Industry (2019) }\end{array}$ \\
\hline Park & $\begin{array}{l}\text { = } 1 \text { if the firm is located in an } \\
\text { industrial estate; } 0 \text { otherwise }\end{array}$ & $\begin{array}{l}\text { IAF (2019) and Zaragoza Chamber of } \\
\text { Commerce and Industry (2019) }\end{array}$ \\
\hline Price & $\begin{array}{l}=1 \text { in } 2004 \text { (non-reformed } \\
\text { water tariff); } 0 \text { otherwise }\end{array}$ & Zaragoza City Council \\
\hline Summer & $=1$ if third quarter; 0 otherwise & \\
\hline
\end{tabular}

Source: Own elaboration

Zaragoza City Council has provided most of the information related to water consumption, pollution and prices. Data related to capital and labour are taken from the SABI database, which includes balance sheet analysis of more than two million Spanish companies. ${ }^{5}$ Both Zaragoza Chamber of Commerce and Industry (2019) and IAF (2019) report information related to firms' location.

Independent variables can be grouped into several areas. First, we include some factors characterizing the firms. The ratio $k l$ is a proxy for capital intensity, calculated by

\footnotetext{
${ }^{5}$ For further information, see https://sabi.bvdinfo.com/
} 
dividing total asset value (includes both tangible and intangible assets; it accounts for accumulated depreciation) by the number of workers. This variable allows us to observe whether and to what extent more capital-intensive firms are more likely to source their water from wells. Moreover, we capture the intensity of water pollution though a weighted index (pollut) calculated by Zaragoza City Council according to the concentration of metals (As, Cd, $\mathrm{Co}, \mathrm{Cr}, \mathrm{Hg}, \mathrm{Ni}, \mathrm{Pb}$, or $\mathrm{Zn}$, among others), $\mathrm{BOD}$ and $\mathrm{COD}$, oil and grease and suspended solids in the wastewater and their impact on water quality. ${ }^{6}$. The index classifies industrial activities into three categories, with higher values indicating higher levels of pollution (Zaragoza City Council, 2013). Finally, we include a dummy variable (product), which takes a value of 1 when water is a key component of the final product, being considered an essential input in the production process and 0 when water is used for other activities (refrigeration, cleaning, etc). This variable is a proxy of the water security and the quality standards required for the firms. Given that firms using water as an essential input may need higher quality water and higher levels of security in water supply we might expect that they use a lower proportion of water drawn from wells. Industries in the food products manufacturing sector or in the brewing sector are the main activities (included in the sample) where water is an essential input.

The next set of variables relates to features of the water sources. The diameter of the meter placed at the interface between public and private water system of each user (msize) is an indicator reflecting the capacity of a user to withdraw water sourced from public network ${ }^{7}$. Additionally, we include the well depth (depth), since it is a proxy to the power and pumping costs involved in extracting water from groundwater sources. We expect that the greater the depth, higher the costs of water taken from wells.

Additionally, we include two variables related to the firm's physical location: the distance to the city centre (distance) and a dummy variable capturing whether or not the firm is located in an industrial estate (park). Location could be a significant issue when making

\footnotetext{
${ }^{6}$ All the wastewater discharges must meet the quality standards established in the Spanish regulations that transpose the European Water Framework Directive (2000/60/EC). Furthermore, the City Council and the River Basin Authority monitor wastewater discharges and they can apply coercive measures in order to enforce these regulations.

${ }^{7}$ The diameter of the meter installed is the same as that of the service pipe bringing water to the user from the main pipeline of the public network. Thus, the diameter of the water meter indicates the maximum quantity of water per hour that a user can withdraw from the public network. Moreover, the larger the diameter of the meter, more simultaneous uses of water can be occurring (for more details see American Water Works Association, 2012).The water meter is mandatory for all users connected to the public water supply network.
} 
decisions related to water sources, since it could have impact on the access to water from different sources.

A variable related to public policies (price) is included. This dummy variable captures the effect of a significant tariff reform that took place in 2004, with a new water tariff in place from 2005 on. The tariff reform implemented affected both the structure and the price level. Before 2005, urban water tariffs were extremely complex, involving both a fixed charge and a variable rate. The fixed charge depended on the diameter of the meter (which varied more widely in the case of industrial users) and street category, while the variable part is calculated by multiplying daily consumption by a single price that increases progressively according to consumption. In this tariff, unlike increasing block tariff, not only additional consumption is charged at the marginal price, but the previous consumption as well. Thus, in 2004, the variable charge contained 205 prices ranging between $€ 0.23 / \mathrm{m}^{3}$ (for a consumption of 0.03 $\mathrm{m}^{3} /$ day) and $€ 1.75 / \mathrm{m}^{3}$ (for a consumption of $135.73 \mathrm{~m}^{3} /$ day). The result was a complicated structure, which made it extremely difficult for customers to have perfect information and a good understanding of the price they were paying for water. In 2005, that complex variable charge was replaced by an increasing block tariff structure, with two consumption blocks. This framework was much simpler, and made the billing system far more transparent ${ }^{8}$. Detailed information on Zaragoza water tariffs is displayed in Tables A1 to A3 (Appendix I).

Finally, a dummy variable capturing seasonal effects (summer) is included, in order to test whether the proportions change significantly during the summer season. Climate conditions and scarcity during the summer could lead to reduced availability and quality of groundwater resources. ${ }^{9}$

\section{Results}

Table 3 displays the main sample statistics. Correlations between independent variables are reported in Table A4 (Appendix II). On average, the firms in the sample source around $46 \%$ of their water from groundwater sources. The average capital-labour ratio is $€ 0.05$

\footnotetext{
${ }^{8}$ Nonetheless, the water tariff reform did not mean significant increases in the price level for industrial users. Even in some cases (i.e. large users) the price level was slightly reduced.

${ }^{9}$ The most significant parameters regarding the physical and chemical quality of groundwater registered in the control stations of the River Basin Authority show significant differences between summer and winter periods (CHE, 2019b). Thus, in the period 2004-2006 it could be observed that groundwater at Zaragoza reached lower concentrations of $\mathrm{NO}_{3}, \mathrm{CO}_{2}, \mathrm{Na}, \mathrm{SO}_{4}, \mathrm{Al}, \mathrm{Fe}$ or $\mathrm{Mg}$ in the winter than in the summer. Other quality parameters such as the levels of BOD and COD, the ph and the temperature of groundwater are also worse in the summer. For more details about the values of the quality parameters see CHE (2019b)
} 
million per worker. For about $10 \%$ of the firms, water is an essential input in their production process. The diameter of the meter of a representative firm is around $90 \mathrm{~mm}$, and the average well depth is 32 meters $^{10}$. Finally, most companies in the sample (67\%) are located in industrial parks, at an average distance of around $3 \mathrm{~km}$ to the city centre.

Table 3. Descriptive statistics

\begin{tabular}{lrrrr}
\hline Variable & Mean & Std. Dev. & Min & Max \\
\hline pwell & 0.4594 & 0.4050 & 0.0000 & 1.0000 \\
$k l$ & 0.0501 & 0.0645 & 0.0009 & 0.4787 \\
pollut & 1.1359 & 0.1369 & 1.0000 & 1.3000 \\
product & 0.1026 & 0.3037 & 0.0000 & 1.0000 \\
msize & 89.3590 & 213.1343 & 13.0000 & 999.0000 \\
depth & 32.3908 & 12.6325 & 9.0000 & 50.0000 \\
distance & 3.1282 & 2.8497 & 0.0000 & 10.0000 \\
park & 0.6667 & 0.4719 & 0.0000 & 1.0000 \\
price & 0.3333 & 0.4719 & 0.0000 & 1.0000 \\
summer & 0.2500 & 0.4335 & 0.0000 & 1.0000 \\
\hline
\end{tabular}

Source: Own elaboration

Tables 4 to 7 show the main results. Table 4 shows the QML estimates of the Fractional Response Model, while Table 5 presents the results of the GEE procedure. The estimated coefficients and their corresponding standard errors are presented in both tables, together with a Wald test for. $H_{0}$ : all slopes zero. Additionally, the estimate of the exchangeable working correlation is included in Table 5 . Note that $k l$ is the only time-varying variable in addition to cross-section varying, so its average value, which we call $k l a v$, is the only component of the $\overline{\mathbf{X}}_{\mathbf{i}}$ vector defined in the previous section.

\footnotetext{
${ }^{10}$ Note that all the industries in the sample are registered as well users, so the well depth is always higher than 0.
} 
Table 4. Fractional Response Model: QML estimates

\begin{tabular}{lllll}
\hline & \multicolumn{2}{l}{ Pooled Fractional Probit Model } & \multicolumn{2}{l}{ Pooled Fractional Logit Model } \\
\hline Variable & Coefficient & Std. Error & Coefficient & Std. Error \\
\hline KI & -0.3673 & 0.5133 & -0.6370 & 0.8734 \\
Pollut & -0.2389 & 0.9837 & -0.3055 & 1.6198 \\
Product & $-1.3067^{* * *}$ & 0.3324 & $-2.1732^{* * *}$ & 0.5764 \\
Msize & $-0.0008^{*}$ & 0.0004 & -0.0013 & 0.0008 \\
Depth & $-0.0195^{*}$ & 0.0107 & $-0.0321^{*}$ & 0.0181 \\
Distance & -0.0608 & 0.0512 & -0.0976 & 0.0851 \\
Park & $0.6834^{*}$ & 0.3512 & $1.1044^{*}$ & 0.5869 \\
Price & -0.1095 & 0.0718 & -0.1837 & 0.1175 \\
Summer & $-0.1045^{* *}$ & 0.0532 & $-0.1717^{* *}$ & 0.0858 \\
kl_av & -0.3666 & 2.6755 & -0.5375 & 4.3280 \\
const. & 0.8151 & 1.1636 & 1.2436 & 1.9109 \\
\hline Wald $\chi^{2}(10)$ & $27.58 * * *$ & & $25.38^{* * *}$ &
\end{tabular}

Note: Data have a panel structure with 39 industries observed in 12 time periods (468 obs.), being kl, price and summer the only time-varying variables, although price and summer are not cross-section-varying. Legend: ${ }^{*}, * *, * *$ indicate statistical significance at the $10 \%, 5 \%$, and $1 \%$ level, respectively. Source: Own elaboration 
Table 5. Fractional Response Model: GEE estimates

\begin{tabular}{lllll}
\hline & \multicolumn{2}{l}{ Fractional Probit Model } & \multicolumn{2}{l}{ Fractional Logit Model } \\
\hline Variable & Coefficient & Std. Error & Coefficient & Std. Error \\
\hline KI & -0.3362 & 0.5195 & -0.5664 & 0.8231 \\
Pollut & -0.2911 & 0.9936 & -0.4604 & 1.6377 \\
Product & $-1.4936 * * *$ & 0.2972 & $-2.5560^{* * *}$ & 0.5468 \\
Msize & -0.0008 & 0.0005 & -0.0013 & 0.0009 \\
Depth & $-0.0200^{*}$ & 0.0110 & $-0.0317^{*}$ & 0.0185 \\
Distance & -0.0626 & 0.0522 & -0.0993 & 0.0857 \\
Park & $0.6670^{*}$ & 0.3528 & $1.0386^{*}$ & 0.5914 \\
Price & -0.1084 & 0.0730 & -0.1828 & 0.1183 \\
Summer & $-0.1035^{*}$ & 0.0543 & $-0.1719 * *$ & 0.0863 \\
kl_av & -0.2266 & 2.6424 & -0.2267 & 4.2456 \\
const. & 0.8954 & 1.1764 & 1.4347 & 1.9458 \\
\hline Working corr. & 0.6732 & & 0.6757 & \\
\hline Wald $\chi^{2}(10)$ & $32.79 * * *$ & & $29.27^{* * *}$ &
\end{tabular}

Note: Data have a panel structure with 39 industries observed in 12 time periods (468 obs.), being kl, price and summer the only time-varying variables, although price and summer are not cross-section-varying.

Legend: $*, * *, * * *$ indicate statistical significance at the $10 \%, 5 \%$, and $1 \%$ level, respectively.

Source: Own elaboration

Results are very similar in terms of significance and signs under both estimation methods (QML and GEE) and the two specifications considered (probit and logit). It can be seen that some firm characteristics, such as capital intensity or the level of water pollution, are not significant in explaining the proportion of water taken from wells. Moreover, no significant influence of price reform is detected.

However, some factors systematically influence the decision regarding the choice of water sources. Regarding the industrial firm characteristics, it seems that companies where water is an essential component of their final products register lower percentages of water taken from groundwater sources. These firms probably require water that meets high quality standards, which the public network system may be more likely to comply with (i.e. bakery or beverages manufacturers).

With respect to the characteristics of water supply systems, we find a negative and statistically significant relationship between the proportion of water coming from wells and the depth of the well that the company is taking water. This result is in line with our 
expectations, since the greater the depth, the higher the pumping costs are likely to be. Although the diameter of the meter is not always significant (only under a probit model estimated using $Q M L)$, the results point to a negative relationship between the diameter of the meter and the proportion of water taken from underground sources. As mentioned before, the diameter of the meter determines the maximum water flow taken from the public network, so finding a negative coefficient in this context is in line with our expectations.

Regarding firm location, being based in an industrial park is a more significant factor than the distance to the city centre. We find that companies based in industrial estates draw higher proportions of water from groundwater sources. On the one hand, some of the industrial parks are located close to the main aquifers, making it easier to get water from groundwater sources (Moreno et al. 2008). On the other hand, this finding makes sense since some of the industrial estates have shared infrastructure and facilities to exploit water from wells, reducing the individual costs for firms to access this source of water. Finally, lower proportions of water coming from wells are registered during the summer, when the quality and availability of groundwater could be much lower.

The marginal (partial) effects are displayed in Tables 6 and 7.

Table 6. Average partial effects: QML

\begin{tabular}{lllll}
\hline & \multicolumn{2}{l}{ Pooled Fractional Probit Model } & \multicolumn{2}{l}{ Pooled Fractional Logit Model } \\
\hline$k l$ & $\mathrm{dy} / \mathrm{dx}$ & Std. Error & $\mathrm{dy} / \mathrm{dx}$ & Std. Error \\
\hline pollut & -0.1311 & 0.1839 & -0.1400 & 0.1920 \\
product & -0.0852 & 0.3510 & -0.0668 & 0.3546 \\
msize & $-0.3890^{* * *}$ & 0.0723 & $-0.3841^{* * *}$ & 0.0715 \\
depth & $-0.0003^{*}$ & 0.0002 & $-0.0003^{*}$ & 0.0002 \\
distance & $-0.0070^{*}$ & 0.0036 & $-0.0070^{*}$ & 0.0037 \\
park & -0.0217 & 0.0179 & -0.0214 & 0.0182 \\
price & $0.2362^{* *}$ & 0.1109 & $0.2326^{* *}$ & 0.1112 \\
summer & -0.0390 & 0.0256 & -0.0402 & 0.0257 \\
\hline
\end{tabular}

Legend: $*, * * * * *$ indicate statistical significance at the $10 \%, 5 \%$, and $1 \%$ level, respectively. Source: own elaboration 
Table 7. Average partial effects: GEE

\begin{tabular}{lllll}
\hline & \multicolumn{2}{l}{ Fractional Probit Model } & \multicolumn{2}{l}{ Fractional Logit Model } \\
\hline$k l$ & $\mathrm{dy} / \mathrm{dx}$ & Std.Error & $\mathrm{dy} / \mathrm{dx}$ & Std.Error \\
\hline pollut & -0.1189 & 0.1844 & -0.1229 & 0.1796 \\
product & -0.1029 & 0.3515 & -0.0999 & 0.3557 \\
msize & $-0.4193^{* * *}$ & 0.0634 & $-0.4180^{* * *}$ & 0.0635 \\
depth & -0.0003 & 0.0002 & -0.0003 & 0.0002 \\
distance & $-0.0071^{*}$ & 0.0037 & $-0.0069^{*}$ & 0.0038 \\
park & -0.0221 & 0.0181 & -0.0215 & 0.0182 \\
price & $0.2282^{* *}$ & 0.1110 & $0.2173^{*}$ & 0.1126 \\
summer & -0.0383 & 0.0258 & -0.0397 & 0.0257 \\
\hline
\end{tabular}

Legend: $* * *, * * *$ indicate statistical significance at the $10 \%, 5 \%$, and $1 \%$ level, respectively. Source: own elaboration

We can highlight two main results. First, even though the msize variable is not significant in the QML logit model, the average partial effect is significant at $10 \%$. Second, the largest marginal effects correspond to park and product. Thus, our findings indicate that the proportion of water drawn from wells is $23 \%$ higher when firms are located in an industrial estate. On the other hand, firms that use water in their production processes draw $40 \%$ less than water from wells than those that are primarily using water for other purposes (e.g. sanitation or refrigeration).

\section{Discussion}

When analysing several water uses demand, modelling decisions on the choice of the water source should be considered. Water users must be correctly characterized for public policies to be effective. In the light of the findings, it is possible to identify some outstanding issues discussed below.

First, the intended use of the water emerges as a significant issue. Supply security and the stringent quality standards guaranteed by the public authorities explain why firms using water as an essential input in their production processes tend to take water from the public network. However, when the water is intended for use in cleaning or refrigerating, for example, we observe a higher proportion of water taken from wells. Firms' location is also a crucial factor; the companies based in industrial parks tend to source a higher proportion of 
their water from wells. On the one hand, companies located in the outskirts of the city will find it much easier (both technically and legally) to drill wells than those in the city centre. On the other hand, the closer the firms are to the city centre, the easier it is for them to access water from the public network. Moreover, companies based in an industrial estate enjoy access to shared infrastructure. This includes infrastructure related to water supply (public network connections and well access) and sewerage, the costs of which are not individually borne. Thus, well drilling is expected to be less costly for those firms.

Furthermore, water sources accessibility has impact on firms' decisions. Thus, those firms not drilling deeply to access the aquifer tend to use higher proportions of groundwater. Additionally, companies that have access to a high instantaneous water flow prefer to take water from public network. Finally, there is a seasonal dimension to the decision on water sources. We observe that firms prefer water from the public network (which is a more reliable supply than well water) during the summer season.

The results obtained also indicate that firms' choice of water source is driven by the water quantity and quality requirements of their production processes. Public authorities responsible for the public supply network (City Council) and groundwater resources (River Basin Authority) should adopt coordinated policies in order to avoid a massive shift from one source to the other. For example, given the level of water prices for industrial users (see footnote 11), a significant increase in water tariffs for industrial users could be necessary to accomplish efficiency and cost recovery objectives. Note that the water tariff reform implemented in 2005 improved the transparency of pricing systems but did not lead to significant increases in the water bill (even for large consumers, the water bill was slightly lower after the reform); as such, no significant effects on the choice of water sources were detected. Nevertheless, at the same time, a price increase could enhance the pressure on groundwater resources as firms seek out cheaper options, affecting both groundwater recharge capacity and quality. This is a relevant issue given the low quality of the groundwater in the Zaragoza area.

The increase of industrial groundwater consumption for low-quality uses, and especially the growth of wells for refrigeration systems could lead to an intense decrease in the water level of the aquifer (and in the quality of groundwater) in the long-run. In this context, an extension of the greywater network (used actually only for public gardens irrigation) throughout the municipal area allowing that industrial users connect it could reduce the pressure on aquifer and on the water public network. (responsibility of the City Council) 
Finally, another important point to stress is linked to the use of land. Given that firm location is a significant issue when choosing among different water sources, public policies aimed at fostering industrial development (especially regarding the creation of industrial parks) should take into account the state of current water bodies. At this point, the expansion of the city based on urbanizations with great garden areas and recreational water related services (e.g. swimming pools) could generate conflicts between users for the groundwater resources. Thus, it is very important to design land use policies in accordance to the capacity of the aquifer to accomplish the traditional industrial uses with the growth of these new residential uses.

\section{Concluding remarks.}

Firms located close to urban areas sometimes have the option of getting water from either the public supply network or from wells with private pumping infrastructure. Choosing the source is a key decision that can have major consequences on both water quality and availability terms. Accordingly, this paper is aimed at analysing the key factors influencing firms' decision about their water source.

In order to identify the factors that have an impact on this decision, we conducted an empirical analysis based on a sample of firms located in the Zaragoza city area (Spain). Since the two water sources under study are complementary, we have used a fractional response methodology to explain the proportion of water that companies take from each source. Results from both estimation methods ( $Q M L$ and GEE), the two specifications considered (probit and logit) and the average partial effects allow us to identify the most significant drivers when choosing water sources. It is very important to emphasize the relevance of this methodology to help water managers to characterize a profile of industrial users according their preferences about two or more different water sources (groundwater o public network, greywater or groundwater, public network or greywater or groundwater, etc.). For this reason, the results obtained in our study would be useful to design more effective demand management measures in the water sector. Adopting policies tailored to the characteristics of users will help to reduce quantitative and qualitative pressures on water resources and to establish long-term shifts in their water consumption patterns.

In sum, the managers of the public network should adopt initiatives adapted to the specific users' characteristics (for example the extension of the greywater network, indicated 
above). Homogeneous treatment of all industrial users could adversely affect the effectiveness of demand-side policies. As we have indicated above, our findings suggest that public policies should be designed according to users' features, and especially according to their economic activity (which determines their use of water) and their location (city centre, industrial estate, etc.).

Although the results of this research are influenced by the hydrogeological characteristics of the analysed area, fractional response models emerge as a very useful tool for explaining decisions related to water sources. This approach complements more traditional methodologies based on the estimation of a water demand function, which do not usually attempt to distinguish between water sources (apart from including a dummy variable indicating the source). In this respect, the paper is an original contribution to the field of water management research, and could be extended to other urban areas.

\section{Acknowledgements}

We would like to thank Juan Arbués for his technical assistance in designing the map.

\section{Funding}

This work was supported by the Spanish Ministry of Economy and Competitiveness and the European Regional Development Fund under Grant ECO2016-75237-R; the National Institute for Agricultural and Food Research and Technology (INIA) under Grant RTA-2017-00082-00-00; and the Government of Aragon (Spain) and the European Social Fund under Grant S23_17R and S40_17R.

\section{References}

American Water Works Association. 2012. Water meters--selection, installation, testing, and maintenance. AWWA manual M6. 5th ed. Denver: American water Works Association.

Arbués, F., García-Valiñas, M.A. and Villanúa, I. 2010. “Urban Water Demand for Service and Industrial Use: The Case of Zaragoza", Water Resources Management 24 (14): 40334048. doi: 10.1007/s11269-010-9645-5.

Baum, C. F. 2008. "Stata tip 63: Modeling proportions." The Stata Journal 8 (2): 299-303.

Black, M. 2016. The atlas of water: mapping the World's most critical resource. Oakland: University of California Press. 
Bluhm, R. 2013 "fhetprob: A fast QMLE Stata routine for fractional probit models with multiplicative heteroscedasticity" http://www.richard-bluhm.com/wpcontent/uploads/2013/02/fhetprob.pdf (Accessed 17 June 2019).

BOE 2001. Royal Decree 1/2001, of 20 July, approving the consolidated text of the Water Act, BOE No. 176, 24 July 2001.

Bovolo, C.I., Blenkinsop, S., Majone, B., Zambrano-Bigiarini, M., Fowler, H.J., Bellin, A., Burton, A., Barceló, D., Grathwohl, P. and Barth, J.A:C., 2010. “Climate Change, Water Resources and Pollution in the Ebro Basin: Towards an Integrated Approach" in Barceló, M. and Petrovic M. (eds) The Ebro River Basin. The Handbook of Environmental Chemistry, vol 13. Berlin: Springer.

CHE 2008 Aluvial del Ebro: Zaragoza, ftp://ftp.chebro.es/Hidrogeologia/FichasMasas/058\%20Aluvial\%20Ebro\%20Zaragoza.pdf (Accessed 14 November 2019).

CHE Plan Hidrológico del 2015 Ebro 2015-21, http://www.chebro.es/contenido.visualizar.do?idContenido=42695\&idMenu=4780 (Accesed 19 October 2019)

CHE 2019a Registro de Aguas. http://iber.chebro.es/webche/ralnfo.aspx (Accessed 19 October 2019).

CHE 2019b Web de Consulta de datos de Aguas subterráneas (WCAS). http://www.datossubterraneas.chebro.es:81/WCAS/ (Accessed 23 October 2019).

Czarnitzki, D. and Kraft, K. 2004. "An empirical test of the asymmetric models on innovative activity: Who invests more into R\&D, the incumbent or the challenger?" Journal of Economic Behavior \& Organization 54 (2): 153-173. doi: 10.1016/j.jebo.2003.01.008.

Eickelpasch, A. and Vogel, A. 2011. "Determinants of the export behaviour of German business services companies." The Service Industries Journal 31(4): 513-526. doi: 10.1080/02642069.2010.504304.

European Commission. 2014. Contribution of Industry on Pollutant Emissions to Air and Water. Luxembourg: Publications Office of the European Union. doi: 10.2779/25422

European Council. 2011. Roadmap to a Resource Efficient Europe. Communication from the Commission to the European Parliament, the Council, the European Economic and Social 
Committee and the Committee of the Regions (COM/2011/ 571 final). http://eurlex.europa.eu/legal-content/EN/TXT/?uri=CELEX:52011DC0571 (Accessed 17 June 2019).

European Environmental Agency. 2017. Climate change, impacts and vulnerability in Europe 2016. Luxembourg: Publications Office of the European Union.

European Environmental Agency. 2018a. EEA Signals. Water is Life. Luxembourg: Publications Office of the European Union. doi: 10.2800/52469

European Environmental Agency. 2018b. "Water management in Europe: price and non-price approaches to water conservation". https://www.eea.europa.eu/themes/water/european-waters/watermanagement/water-management-in-europe(Accessed 17 June 2019).

European Environmental Agency. 2019a "Climate change poses increasingly severe risks for ecosystems, human health and the economy in Europe". https://www.eea.europa.eu/highlights/climate-change-poses-increasingly-severe (Accessed 15 January 2020)

European Environmental Agency. 2019b "Water use and environmental pressures" https://www.eea.europa.eu/themes/water/european-waters/water-use-andenvironmental-pressures/water-use-and-environmental-pressures\#toc-2 (Accessed 10 January 2020).

European Environmental Agency. 2019c. "Water use in Europe. Quantity and quality face big challenges". https://www.eea.europa.eu/themes/water/european-waters/watermanagement/water-management-in-europe (Accessed 17 June 2019).

EUROSTAT. 2019a. Water use by supply category and economical sector [env_wat_cat]. http://appsso.eurostat.ec.europa.eu/nui/show.do?dataset=env wat cat\&lang=en (Accessed 10 January 2020).

EUROSTAT. 2019b. Water use in the manufacturing industry by activity and supply category [env_wat_ind].

http://appsso.eurostat.ec.europa.eu/nui/show.do?dataset=ENV WAT IND\&lang=en (Accessed 10 January 2020).

Fakih, A. and Ghazalian, P.L. 2014. "Which firms export? An empirical analysis for the manufacturing sector in the MENA region." Journal of Economic Studies 41(5): 672-695. 
doi: 10.1108/JES-10-2012-0142.

Fatima, S.T. and Khan, A.Q. 2019. "Globalization and female labor force participation: The role of trading partners." Journal of International Trade and Economic Development 28(3): 365-390. doi: 10.1080/09638199.2018.1545140.

Flörke, M., Schneider, C. and McDonald, R.I. 2018 "Water competition between cities and agriculture driven by climate change and urban growth." Nature Sustainability, 1: 51-58. doi: 10.1038/s41893-017-0006-8

Fornés, J.M., de la Hera, A., Llamas, R and Martínez-Santos, P. 2007. "Legal Aspects Of Groundwater Ownership In Spain" Water International, 32: 676-684. doi: 10.1080/02508060.2007.9709698.

García-Gil, A., Vázquez-Suñe, E., Garrido-Schneider E., Sánchez-Navarro, J.A. and Mateo-Lázaro J. 2014. "The thermal consequences of river-level variations in an urban groundwater body highly affected by groundwater heat pumps." Science of The Total Environment 485-486: 575-587. doi: 10.1016/j.scitotenv.2014.03.123.

Garrido, E.; San Román, J.; Azcón, A.; Sánchez-Navarro, J.A.; García-Gil, A.; Celador, R.; Moreno, L,; Vázquez, E.; Elorza, F.; y Rivas, E. 2014 Análisis del Impacto térmico generado por los pozos de climatización en las aguas subterráneas de la ciudad de Zaragoza, IGME-CHE, Zaragoza, Spain.

GISS (2019) GISTEMP Team, 2019: GISS Surface Temperature Analysis (GISTEMP), version 4. https://data.giss.nasa.gov/gistemp/Surface Temperature Analysis (Accessed 3 November 2019).

Greene, W.H. and Hensher, A.D. 2010. Modeling Ordered Choices. New York: Cambridge University Pres.

IAF. 2019. Suelo Industrial en Aragón. https://www.iaf.es/poligonos/ (Accessed 17 June 2019).

Ibisch, R., Austnes, K., Borchardt, D., Boteler, B., Leujak, W., Lukat, E., Rouillard, J., Schmedtje, U., Solheim, A.L. and Westphal, K. 2016. "European assessment of eutrophication abatement measures across land-based sources, inland, coastal and marine waters". ETC/ICM Technical Report 2/2016 European Topic Centre on Inland, Coastal and Marine Waters, Magdeburg. 
IGME. 2020. Base de datos de Puntos de Agua del IGME. http://info.igme.es/BDAguas/ (Accessed 20 January 2020).

INE. 2018a. Official population figures from Spanish municipalities: Revision of the Municipal Register. http://www.ine.es/dynt3/inebase/en/index.htm?padre=527 (Accessed 17 June 2019).

INE. 2018b. Urban Indicators (Urban Audit). http://www.ine.es/jaxiT3/Tabla.htm?t=10849 (Accessed 17 June 2019)).

INE. 2018c. Statistical Use of the Central Business Register. http://www.ine.es/dyngs/INEbase/es/operacion.htm?c=Estadistica C\&cid=1254736160 $\underline{707 \& \text { menu=ultiDatos\&idp }=1254735576550}$ (Accessed 17 June 2019).

Jeuken, A., Termansen, M., Antonellini, M., Olsthoorn, T. and van Beek, E. 2017. “Climate Proof Fresh Water Supply in Coastal Areas and Deltas in Europe", Water Resources Management 31:583-586. doi: 10.1007/s11269-016-1560-y.

Kang, L.S. and Nanda, P. 2018. "What determines the disclosure of managerial remuneration in India?" Journal of Financial Reporting and Accounting 16 (1): 2-23. doi: 10.1108/JFRA-042015-0050.

Koch, S.F. 2010. "Fractional Multinomial Response Models with an Application to Expenditure Shares". Working Paper 2010-21. University of Pretoria.

Kölling, A. 2018. "It's not about adjustment costs: Estimating asymmetries in long-run labor demand using a fractional panel probit model”. Working Paper 95. Berlin School of Economics and Law, Institute of Management Berlin.

Krueger, E., Suresh, P., Raoc, C. and Borchardtd, D. 2019 "Quantifying urban water supply security under global change." Global Environmental Change 56: 66-74. doi: /10.1016/j.gloenvcha.2019.03.009

Liang, K.Y. and Zeger, S.L. 1986 "Longitudinal data analysis using generalized linear models." Biometrika 73: 13-22. doi: 10.1093/biomet/73.1.13.

Lopez-Gunn, E., Zorrilla, P., Prieto, F. and Llamas, M. 2012. "Lost in translation? Water efficiency in Spanish agriculture." Agricultural Water Management 108: 83-95. doi: doi.org/10.1016/j.agwat.2012.01.005.

Loudermilk, M.S. 2007. “Estimation of Fractional Dependent Variables in Dynamic Panel Data 
Models with an Application to Firm Dividend Policy." Journal of Business \& Economic Statistics 25: 462-472. doi: 10.1198/073500107000000098.

Lutz, S. and Merz, R. 2016. "Recent Trends in the Ebro River Basin: Is It All 'Just' Climate Change?" Geophysical Research Abstracts, 18: EGU2016-9218.

MAPAMA 2019. GeoPortal. https://sig.mapama.gob.es/geoportal/ (Accessed 15 November 2019).

Martínez-Espiñeira, R., García-Rubio, M.A. and González-Gómez, F. 2017. "Which factors, and to what extent, influence the condition of urban water distribution networks. An empirical analysis of the Spanish case." Water Resources and Economics 18: 20-23. doi: doi.org/10.1016/j.wre.2017.02.002.

Moreno, L., Garrido, E.A., Azcón, A and Durán, J.J. 2008. Hidrogeología Urbana de Zaragoza. Madrid: Instituto Geológico y Minero de España.

Nauges, C. and Strand, J. 2017. "Water Hauling and Girls' School Attendance: Some New Evidence from Ghana." Environmental and Resource Economics 66: 65-88. doi: 10.1007/s10640-017-0194-8.

Omedas, M., Galván, R. and Gómez, C.M. 2011 Water planning towards a green economy in the Ebro River Basin. Paper presented at the UN-Water International Conference, Zaragoza, October 3-5.

https://www.un.org/waterforlifedecade/green economy 2011/pdf/water planning ca ses ebro.pdf (Accessed 13 January 2020).

Padedda, B.M., Sechi, N., Lai, G.G., Mariani, M.A., Pulina, S., Sarria, M., Satta, C.T., Virdis, T., Buscarinu, P. and Lugliè, A. 2017. "Consequences of eutrophication in the management of water resources in Mediterranean reservoirs: A case study of Lake Cedrino (Sardinia, Italy), Global Ecology and Conservation 12: 21-35. doi: 10.1016/j.gecco.2017.08.004.

Papke, L.E. and Wooldridge J.M. 1996. "Econometric methods for fractional response variables with an application to 401(k) plan participation rates." Journal of Applied Econometrics 11: 619-632. doi: 10.1002/(SICI)1099-1255(199611)11:6<619::AID-JAE418>3.0.CO;2-1.

Papke, L.E. and Wooldridge, J.M. 2008. "Panel data methods for fractional response variables with an application to test pass rates." Journal of Econometrics 145: 121-133. doi: 10.1016/j.jeconom.2008.05.009. 
Rees, J.A. 1969. Industrial demand of water: a study of South East England. London: Weidenfeld and Nicholson.

Renzetti, S. 1993. "Examining the Differences in Self- and Publicly Supplied Firms' Water Demands." Land Economics 69: 181-188. doi: 10.2307/3146518

Reynaud, A. 2003. "An econometric estimation of industrial water demand in France." Environmental Resources Economics, 25 (2): 213-232. doi: 10.1023/A:1023992322236.

Ritchie, H. and Roser, M. 2020. Water Use and Stress. https://ourworldindata.org/water-usestress' (Accessed 12 January 2020).

Sengupta, P.K. 2018. Industrial Water Resource Management: Challenges and Opportunities for Corporate Water Stewardship. Hoboken: John Wiley \& Sons.

Vargas, J. and Paneque, P. 2019 "Challenges for the Integration of Water Resource and Drought-Risk Management in Spain." Sustainability 11: 308. doi: 10.3390/su11020308

Versini, P.A., Pouget, L., McEnnis, S., Custodio, E. and Escaler, I. 2016. "Climate change impact on water resources availability: case study of the Llobregat River basin (Spain), Hidrological Sciences Journal, 61: 2496-2508. doi: 10.1080/02626667.2016.1154556

Villoria, N.B. and Liu, J. 2018. "Using spatially explicit data to improve our understanding of land supply responses: An application to the cropland effects of global sustainable irrigation in the Americas." Land Use Policy 75: 411-419. doi: 10.1016/j.landusepol.2018.04.010.

Wagner, J. 2003. "Unobserved firm and the size-exports nexus: Evidence from German panel data." Review of World Economics 139 (1): 161-172. doi: 10.1007/BF02659612.

Williams, R. 2018. “Analyzing Proportions: Fractional Response and Zero One Inflated Beta Models." https://www3.nd.edu/ rwilliam/ (Accessed 17 June 2019).

Wooldridge, J.M. 2002. Econometric analysis of cross section and panel data. Cambridge (MA): The MIT Press.

Wooldridge, J.M. 2011. Fractional response models with endogeneous explanatory variables and heterogeneity. Paper presented at the Stata Conference, Chicago, July 14-15. https://www.stata.com/meeting/chicago11/materials/chi11_wooldridge.pdf (Accessed 12 June 2019). 
Zaragoza Chamber of Commerce and Industry 2019. Suelo industrial en Zaragoza y Provincia. https://www.camarazaragoza.com/poligonos/html/mapa poligonos.asp (Accessed 17 June 2019).

Zaragoza City Council 2004 Ordenanza Fiscal n²4.25. Tasa por la prestación de servicios de abastecimiento de agua potable y saneamiento de aguas residuales http://www.zaragoza.es/contenidos/normativa/ordenanzas-

fiscales/2004/ordenanza 24 25.pdf (Accessed 12 November 2019)

Zaragoza City Council 2005. Ordenanza Fiscal n²4.25. Tasa por la prestación de servicios de abastecimiento de agua potable y saneamiento de aguas residuales http://www.zaragoza.es/contenidos/normativa/ordenanzas-fiscales/2005/ord24 25.pdf (Accessed 12 November 2019)

Zaragoza City Council 2006. Ordenanza Fiscal n²4.25. Tasa por la prestación de servicios de abastecimiento de agua potable y saneamiento de aguas residuales http://www.zaragoza.es/contenidos/normativa/ordenanzas-fiscales/2006/2425_06.pdf (Accessed 12 November 2019)

Zaragoza City Council 2013. Ordenanza Municipal para la Ecoeficiencia y la Calidad de la Gestión Integral del Agua. https://www.zaragoza.es/sede/servicio/normativa/1542 (Accessed 12 November 2019) 


\section{Appendix I}

Table A1. Zaragoza water tariff (2004)

\begin{tabular}{|c|c|c|c|}
\hline $\begin{array}{c}\text { Consumption } \\
\left(\mathbf{m}^{3} / \text { day }\right)\end{array}$ & $\begin{array}{c}\text { Supply } \\
\left(\boldsymbol{\epsilon} / \mathbf{m}^{3}\right)\end{array}$ & $\begin{array}{c}\text { Sewerage } \\
\left(\boldsymbol{\epsilon} / \mathbf{m}^{3}\right)\end{array}$ & $\begin{array}{c}\text { Total } \\
\left(\boldsymbol{\epsilon} / \mathbf{m}^{3}\right)\end{array}$ \\
\hline 0.030000 & 0.124420 & 0.105580 & 0.23 \\
\hline 0.205000 & 0.126974 & 0.103026 & 0.23 \\
\hline 0.210256 & 0.133527 & 0.106473 & 0.24 \\
\hline 0.215790 & 0.133353 & 0.106647 & 0.24 \\
\hline 0.221622 & 0.141967 & 0.108033 & 0.25 \\
\hline 0.227778 & 0.146675 & 0.113325 & 0.26 \\
\hline 0.234286 & 0.147940 & 0.112060 & 0.26 \\
\hline 0.241177 & 0.159501 & 0.120499 & 0.28 \\
\hline 0.248485 & 0.163310 & 0.126690 & 0.29 \\
\hline 0.256250 & 0.166014 & 0.123986 & 0.29 \\
\hline 0.264516 & 0.171776 & 0.128224 & 0.30 \\
\hline 0.273333 & 0.171752 & 0.128248 & 0.30 \\
\hline 0.282759 & 0.179728 & 0.130272 & 0.31 \\
\hline 0.292857 & 0.189546 & 0.140454 & 0.33 \\
\hline 0.303704 & 0.190962 & 0.139038 & 0.33 \\
\hline 0.315385 & 0.198859 & 0.141141 & 0.34 \\
\hline 0.328000 & 0.203515 & 0.146485 & 0.35 \\
\hline 0.341667 & 0.206374 & 0.143626 & 0.35 \\
\hline 0.356522 & 0.212827 & 0.147173 & 0.36 \\
\hline 0.372727 & 0.212955 & 0.147045 & 0.36 \\
\hline 0.390476 & 0.221781 & 0.148219 & 0.37 \\
\hline 0.410000 & 0.226793 & 0.153207 & 0.38 \\
\hline 0.431579 & 0.228362 & 0.151638 & 0.38 \\
\hline 0.437143 & 0.234578 & 0.155422 & 0.39 \\
\hline 0.441346 & 0.237383 & 0.162617 & 0.40 \\
\hline & & & \\
\hline
\end{tabular}

\begin{tabular}{|c|c|c|c|}
\hline $\begin{array}{c}\text { Consumption } \\
\left(\mathbf{m}^{\mathbf{3}} / \mathbf{d a y}\right)\end{array}$ & $\begin{array}{c}\text { Supply } \\
\left(\boldsymbol{\epsilon} / \mathbf{m}^{\mathbf{3}}\right)\end{array}$ & $\begin{array}{c}\text { Sewerage } \\
\left(\boldsymbol{€} / \mathbf{m}^{\mathbf{3}} \mathbf{)}\right.\end{array}$ & $\begin{array}{c}\text { Total } \\
\left(\boldsymbol{(} / \mathbf{m}^{\mathbf{3}}\right)\end{array}$ \\
\hline 0.445631 & 0.239396 & 0.160604 & 0.40 \\
\hline 0.450000 & 0.243845 & 0.166155 & 0.41 \\
\hline 0.454455 & 0.243130 & 0.166870 & 0.41 \\
\hline 0.459000 & 0.250109 & 0.169891 & 0.42 \\
\hline 0.463636 & 0.253117 & 0.176883 & 0.43 \\
\hline 0.468367 & 0.253846 & 0.176154 & 0.43 \\
\hline 0.473196 & 0.259583 & 0.180417 & 0.44 \\
\hline 0.478125 & 0.266604 & 0.193396 & 0.46 \\
\hline 0.483158 & 0.271750 & 0.198250 & 0.47 \\
\hline 0.488298 & 0.271195 & 0.198805 & 0.47 \\
\hline 0.493548 & 0.279023 & 0.200977 & 0.48 \\
\hline 0.498913 & 0.282729 & 0.207271 & 0.49 \\
\hline 0.504396 & 0.283616 & 0.206384 & 0.49 \\
\hline 0.510000 & 0.290051 & 0.209949 & 0.50 \\
\hline 0.515730 & 0.288210 & 0.211790 & 0.50 \\
\hline 0.521591 & 0.296041 & 0.213959 & 0.51 \\
\hline 0.527586 & 0.300234 & 0.219766 & 0.52 \\
\hline 0.533721 & 0.303045 & 0.226955 & 0.53 \\
\hline 0.540000 & 0.307463 & 0.232537 & 0.54 \\
\hline 0.546429 & 0.312886 & 0.237114 & 0.55 \\
\hline 0.553012 & 0.311194 & 0.238806 & 0.55 \\
\hline 0.559756 & 0.317952 & 0.242048 & 0.56 \\
\hline 0.566667 & 0.326768 & 0.253232 & 0.58 \\
\hline 0.573750 & 0.326518 & 0.253482 & 0.58 \\
\hline 0.581013 & 0.333863 & 0.256137 & 0.59 \\
\hline & & & \\
\hline
\end{tabular}

\begin{tabular}{|c|c|c|c|}
\hline $\begin{array}{c}\text { Consumption } \\
\left(\mathbf{m}^{\mathbf{3}} / \mathbf{d a y}\right)\end{array}$ & $\begin{array}{c}\text { Supply } \\
\left(\boldsymbol{\epsilon} / \mathbf{m}^{3}\right)\end{array}$ & $\begin{array}{c}\text { Sewerage } \\
\left(\boldsymbol{\epsilon} / \mathbf{m}^{3}\right)\end{array}$ & $\begin{array}{c}\text { Total } \\
\left(\boldsymbol{\epsilon} / \mathbf{m}^{3}\right)\end{array}$ \\
\hline 0.588462 & 0.337304 & 0.262696 & 0.60 \\
\hline 0.596104 & 0.338496 & 0.261504 & 0.60 \\
\hline 0.603947 & 0.344401 & 0.265599 & 0.61 \\
\hline 0.612000 & 0.346818 & 0.273182 & 0.62 \\
\hline 0.620270 & 0.351282 & 0.278718 & 0.63 \\
\hline 0.628767 & 0.351190 & 0.278810 & 0.63 \\
\hline 0.637500 & 0.358232 & 0.281768 & 0.64 \\
\hline 0.646479 & 0.360824 & 0.289176 & 0.65 \\
\hline 0.655714 & 0.362171 & 0.287829 & 0.65 \\
\hline 0.665217 & 0.367074 & 0.292926 & 0.66 \\
\hline 0.675000 & 0.365697 & 0.294303 & 0.66 \\
\hline 0.685075 & 0.372458 & 0.297542 & 0.67 \\
\hline 0.695455 & 0.375920 & 0.304080 & 0.68 \\
\hline 0.706154 & 0.375984 & 0.304016 & 0.68 \\
\hline 0.717188 & 0.382174 & 0.307826 & 0.69 \\
\hline 0.728571 & 0.390016 & 0.319984 & 0.71 \\
\hline 0.740323 & 0.391521 & 0.318479 & 0.71 \\
\hline 0.752459 & 0.397121 & 0.322879 & 0.72 \\
\hline 0.765000 & 0.395900 & 0.324100 & 0.72 \\
\hline 0.777966 & 0.403514 & 0.326486 & 0.73 \\
\hline 0.791379 & 0.407671 & 0.332329 & 0.74 \\
\hline 0.805263 & 0.407892 & 0.332108 & 0.74 \\
\hline 0.819643 & 0.414560 & 0.345440 & 0.76 \\
\hline 0.834546 & 0.416222 & 0.343778 & 0.76 \\
\hline 0,850000 & 0,421318 & 0,348682 & 0,77 \\
\hline & & & \\
\hline
\end{tabular}


Table A1. Zaragoza water tariff (2004) (continuation)

\begin{tabular}{|c|c|c|c|}
\hline $\begin{array}{c}\text { Consumption } \\
\left(\mathbf{m}^{\mathbf{3}} / \mathbf{d a y}\right)\end{array}$ & $\begin{array}{c}\text { Supply } \\
\left(\mathbf{\epsilon} / \mathbf{m}^{\mathbf{3}} \mathbf{)}\right.\end{array}$ & $\begin{array}{c}\text { Sewerage } \\
\left(\mathbf{\epsilon} / \mathbf{m}^{\mathbf{3}} \mathbf{)}\right.\end{array}$ & $\begin{array}{c}\text { Total } \\
\left(\mathbf{\epsilon} / \mathbf{m}^{\mathbf{3}} \mathbf{)}\right.\end{array}$ \\
\hline 0,866038 & 0,420251 & 0,349749 & 0,77 \\
\hline 0,882692 & 0,427017 & 0,352983 & 0,78 \\
\hline 0,900000 & 0,430171 & 0,359829 & 0,79 \\
\hline 0,918000 & 0,430547 & 0,359453 & 0,79 \\
\hline 0,936735 & 0,436430 & 0,363570 & 0,80 \\
\hline 0,956250 & 0,439025 & 0,370975 & 0,81 \\
\hline 0,976596 & 0,440843 & 0,369157 & 0,81 \\
\hline 0,997826 & 0,455308 & 0,384692 & 0,84 \\
\hline 1,020000 & 0,454400 & 0,385600 & 0,84 \\
\hline 1,043182 & 0,462232 & 0,387768 & 0,85 \\
\hline 1,067442 & 0,466298 & 0,393702 & 0,86 \\
\hline 1,092857 & 0,466831 & 0,393169 & 0,86 \\
\hline 1,119512 & 0,473626 & 0,396374 & 0,87 \\
\hline 1,147500 & 0,477289 & 0,402711 & 0,88 \\
\hline 1,170115 & 0,480986 & 0,409014 & 0,89 \\
\hline 1,180290 & 0,480326 & 0,409674 & 0,89 \\
\hline 1,190643 & 0,491106 & 0,418894 & 0,91 \\
\hline 1,201180 & 0,491888 & 0,418112 & 0,91 \\
\hline 1,211905 & 0,497770 & 0,422230 & 0,92 \\
\hline 1,222823 & 0,500676 & 0,429324 & 0,93 \\
\hline 1,233939 & 0,502898 & 0,427102 & 0,93 \\
\hline 1,245260 & 0,507341 & 0,432659 & 0,94 \\
\hline 1,256790 & 0,506834 & 0,433166 & 0,94 \\
\hline 1,268536 & 0,513910 & 0,436090 & 0,95 \\
\hline 1,280503 & 0,522561 & 0,447439 & 0,97 \\
\hline 1,292698 & 0,523498 & 0,446502 & 0,97 \\
\hline
\end{tabular}

\begin{tabular}{|c|c|c|c|}
\hline $\begin{array}{c}\text { Consumption } \\
\left(\mathbf{m}^{\mathbf{3}} / \mathbf{d a y}\right)\end{array}$ & $\begin{array}{c}\text { Supply } \\
\left(\mathbf{\epsilon} / \mathbf{m}^{\mathbf{3}}\right)\end{array}$ & $\begin{array}{c}\text { Sewerage } \\
\left(\mathbf{\epsilon} / \mathbf{m}^{\mathbf{~}}\right)\end{array}$ & $\begin{array}{c}\text { Total } \\
\left(\mathbf{\epsilon} / \mathbf{m}^{\mathbf{3}} \mathbf{)}\right.\end{array}$ \\
\hline 1,305128 & 0,530076 & 0,449924 & 0,98 \\
\hline 1,317799 & 0,533833 & 0,456167 & 0,99 \\
\hline 1,330719 & 0,536210 & 0,453790 & 0,99 \\
\hline 1,343894 & 0,541348 & 0,458652 & 1,00 \\
\hline 1,357333 & 0,540998 & 0,459002 & 1,00 \\
\hline 1,371044 & 0,548864 & 0,461136 & 1,01 \\
\hline 1,385034 & 0,549955 & 0,470045 & 1,02 \\
\hline 1,399313 & 0,555629 & 0,474371 & 1,03 \\
\hline 1,413889 & 0,553992 & 0,476008 & 1,03 \\
\hline 1,428772 & 0,561069 & 0,478931 & 1,04 \\
\hline 1,443972 & 0,561250 & 0,488750 & 1,05 \\
\hline 1,459498 & 0,568110 & 0,491890 & 1,06 \\
\hline 1,475362 & 0,571017 & 0,498983 & 1,07 \\
\hline 1,491575 & 0,572265 & 0,497735 & 1,07 \\
\hline 1,508148 & 0,582685 & 0,507315 & 1,09 \\
\hline 1,525094 & 0,581203 & 0,508797 & 1,09 \\
\hline 1,542424 & 0,589131 & 0,510869 & 1,10 \\
\hline 1,560153 & 0,593959 & 0,516041 & 1,11 \\
\hline 1,578295 & 0,593920 & 0,516080 & 1,11 \\
\hline 1,596863 & 0,601260 & 0,518740 & 1,12 \\
\hline 1,615873 & 0,604802 & 0,525198 & 1,13 \\
\hline 1,635341 & 0,606204 & 0,523796 & 1,13 \\
\hline 1,655285 & 0,612103 & 0,527897 & 1,14 \\
\hline 1,675720 & 0,610776 & 0,529224 & 1,14 \\
\hline 1,696667 & 0,618388 & 0,531612 & 1,15 \\
\hline 1,718144 & 0,621994 & 0,538006 & 1,16 \\
\hline & & & \\
\hline
\end{tabular}

\begin{tabular}{|c|c|c|c|}
\hline $\begin{array}{c}\text { Consumption } \\
\left(\mathrm{m}^{3} / \text { day }\right)\end{array}$ & $\begin{array}{l}\text { Supply } \\
\left(€ / \mathrm{m}^{3}\right)\end{array}$ & $\begin{array}{c}\text { Sewerage } \\
\left(€ / \mathrm{m}^{3}\right)\end{array}$ & $\begin{array}{c}\text { Total } \\
\left(€ / \mathrm{m}^{3}\right)\end{array}$ \\
\hline 1,740171 & 0,622110 & 0,537890 & 1,16 \\
\hline 1,762771 & 0,628444 & 0,541556 & 1,17 \\
\hline 1,785965 & 0,631136 & 0,548864 & 1,18 \\
\hline 1,809778 & 0,632695 & 0,547305 & 1,18 \\
\hline 1,834234 & 0,637589 & 0,552411 & 1,19 \\
\hline 1,859361 & 0,636418 & 0,553582 & 1,19 \\
\hline 1,885185 & 0,643279 & 0,556721 & 1,20 \\
\hline 1,911737 & 0,651931 & 0,568069 & 1,22 \\
\hline 1,939048 & 0,652202 & 0,567798 & 1,22 \\
\hline 1,967150 & 0,659016 & 0,580984 & 1,24 \\
\hline 1,996078 & 0,660728 & 0,579272 & 1,24 \\
\hline 2,025871 & 0,665478 & 0,584522 & 1,25 \\
\hline 2,056566 & 0,673189 & 0,586811 & 1,26 \\
\hline 2,088205 & 0,677335 & 0,592665 & 1,27 \\
\hline 2,120833 & 0,677760 & 0,592240 & 1,27 \\
\hline 2,154497 & 0,684335 & 0,595665 & 1,28 \\
\hline 2,189247 & 0,687028 & 0,602972 & 1,29 \\
\hline 2,225137 & 0,688894 & 0,601106 & 1,29 \\
\hline 2,262222 & 0,693477 & 0,606523 & 1,30 \\
\hline 2,300565 & 0,692617 & 0,607383 & 1,30 \\
\hline 2,340230 & 0,699478 & 0,610522 & 1,31 \\
\hline 2,381287 & 0,702620 & 0,617380 & 1,32 \\
\hline 2,423810 & 0,703199 & 0,616801 & 1,32 \\
\hline 2,467879 & 0,709071 & 0,620929 & 1,33 \\
\hline 2,513580 & 0,717162 & 0,632838 & 1,35 \\
\hline 2,561006 & 0,720704 & 0,639296 & 1,36 \\
\hline
\end{tabular}


Table A1. Zaragoza water tariff (2004) (continuation)

\begin{tabular}{|c|c|c|c|}
\hline $\begin{array}{c}\text { Consumption } \\
\left(\mathrm{m}^{3} / \text { day }\right)\end{array}$ & $\begin{array}{l}\text { Supply } \\
\left(€ / \mathrm{m}^{3}\right)\end{array}$ & $\begin{array}{c}\text { Sewerage } \\
\left(€ / \mathrm{m}^{3}\right)\end{array}$ & $\begin{array}{c}\text { Total } \\
\left(€ / \mathrm{m}^{3}\right)\end{array}$ \\
\hline 2,610256 & 0,719998 & 0,640002 & 1,36 \\
\hline 2,661438 & 0,727710 & 0,642290 & 1,37 \\
\hline 2,714667 & 0,736971 & 0,653029 & 1,39 \\
\hline 2,770068 & 0,737708 & 0,652292 & 1,39 \\
\hline 2,827778 & 0,744489 & 0,655511 & 1,40 \\
\hline 2,887943 & 0,747749 & 0,662251 & 1,41 \\
\hline 2,950725 & 0,749926 & 0,660074 & 1,41 \\
\hline 3,016296 & 0,754418 & 0,665582 & 1,42 \\
\hline 3,084849 & 0,753866 & 0,666134 & 1,42 \\
\hline 3,156589 & 0,760236 & 0,679764 & 1,44 \\
\hline 3,231746 & 0,761126 & 0,678874 & 1,44 \\
\hline 3,310569 & 0,766905 & 0,683095 & 1,45 \\
\hline 3,393333 & 0,769814 & 0,690186 & 1,46 \\
\hline 3,480342 & 0,772147 & 0,687853 & 1,46 \\
\hline 3,571930 & 0,782082 & 0,697918 & 1,48 \\
\hline 3,668469 & 0,781686 & 0,698314 & 1,48 \\
\hline 3,770370 & 0,789601 & 0,700399 & 1,49 \\
\hline 3,878095 & 0,793361 & 0,706639 & 1,50 \\
\hline 3,992157 & 0,794407 & 0,705593 & 1,50 \\
\hline 4,113131 & 0,800880 & 0,709120 & 1,51 \\
\hline 4,241667 & 0,799198 & 0,710802 & 1,51 \\
\hline 4,378495 & 0,807127 & 0,712873 & 1,52 \\
\hline
\end{tabular}

\begin{tabular}{|c|c|c|c|}
\hline $\begin{array}{c}\text { Consumption } \\
\left(\mathbf{m}^{\mathbf{3}} / \mathbf{d a y}\right)\end{array}$ & $\begin{array}{c}\text { Supply } \\
\left(\boldsymbol{\epsilon} / \mathbf{m}^{\mathbf{3}} \mathbf{)}\right.\end{array}$ & $\begin{array}{c}\text { Sewerage } \\
\left(\boldsymbol{\epsilon} / \mathbf{m}^{\mathbf{3}} \mathbf{)}\right.\end{array}$ & $\begin{array}{c}\text { Total } \\
\left(\boldsymbol{(} / \mathbf{m}^{\mathbf{3}} \mathbf{)}\right.\end{array}$ \\
\hline 4,524444 & 0,812159 & 0,717841 & 1,53 \\
\hline 4,680460 & 0,811919 & 0,718081 & 1,53 \\
\hline 4,847619 & 0,818977 & 0,721023 & 1,54 \\
\hline 5,027161 & 0,821888 & 0,728112 & 1,55 \\
\hline 5,220513 & 0,823089 & 0,726911 & 1,55 \\
\hline 5,429333 & 0,828558 & 0,731442 & 1,56 \\
\hline 5,655556 & 0,827030 & 0,732970 & 1,56 \\
\hline 5,901449 & 0,834111 & 0,735889 & 1,57 \\
\hline 6,169697 & 0,834291 & 0,745709 & 1,58 \\
\hline 6,463492 & 0,841047 & 0,748953 & 1,59 \\
\hline 6,786667 & 0,849757 & 0,760243 & 1,61 \\
\hline 7,143860 & 0,857415 & 0,762585 & 1,62 \\
\hline 7,540741 & 0,856042 & 0,763958 & 1,62 \\
\hline 7,984314 & 0,863970 & 0,766030 & 1,63 \\
\hline 8,483333 & 0,868693 & 0,771307 & 1,64 \\
\hline 9,048889 & 0,868762 & 0,771238 & 1,64 \\
\hline 9,695238 & 0,876211 & 0,773789 & 1,65 \\
\hline 10,441026 & 0,877673 & 0,782327 & 1,66 \\
\hline 11,311111 & 0,882612 & 0,787388 & 1,67 \\
\hline 12,339394 & 0,881397 & 0,788603 & 1,67 \\
\hline 13,573333 & 0,888257 & 0,791743 & 1,68 \\
\hline 15,081482 & 0,891757 & 0,798243 & 1,69 \\
\hline & & & \\
\hline
\end{tabular}

\begin{tabular}{|c|c|c|c|}
\hline $\begin{array}{c}\text { Consumption } \\
\left(\mathbf{m}^{\mathbf{3}} / \mathbf{d a y}\right)\end{array}$ & $\begin{array}{c}\text { Supply } \\
\left(\mathbf{\epsilon} / \mathbf{m}^{\mathbf{3}} \mathbf{)}\right.\end{array}$ & $\begin{array}{c}\text { Sewerage } \\
\left(\mathbf{\epsilon} / \mathbf{m}^{\mathbf{3}} \mathbf{)}\right.\end{array}$ & $\begin{array}{c}\text { Total } \\
\left(\mathbf{\epsilon} / \mathbf{m}^{\mathbf{3}} \mathbf{)}\right.\end{array}$ \\
\hline 16,966667 & 0,891981 & 0,798019 & 1,69 \\
\hline 19,390476 & 0,898209 & 0,801791 & 1,70 \\
\hline 22,622222 & 0,900902 & 0,809098 & 1,71 \\
\hline 27,146667 & 0,902569 & 0,807431 & 1,71 \\
\hline 33,933333 & 0,912505 & 0,817495 & 1,73 \\
\hline 45,244444 & 0,911443 & 0,818557 & 1,73 \\
\hline 67,866667 & 0,919156 & 0,820844 & 1,74 \\
\hline 135,733333 & 0,923350 & 0,826650 & 1,75 \\
\hline
\end{tabular}

Source: Zaragoza City Council (2004) 
Table A2. Zaragoza water tariff (2005)

\begin{tabular}{|c|c|c|c|}
\hline $\begin{array}{c}\text { Consumption } \\
\left(\mathbf{m}^{\mathbf{3}} / \text { day) }\right.\end{array}$ & $\begin{array}{c}\text { Supply } \\
\left(\boldsymbol{\epsilon} / \mathbf{m}^{\mathbf{3}}\right)\end{array}$ & $\begin{array}{c}\text { Sewerage } \\
\left(\boldsymbol{€} / \mathbf{m}^{\mathbf{3}}\right)\end{array}$ & $\begin{array}{c}\text { Total } \\
\left(\boldsymbol{\epsilon} / \mathbf{m}^{\mathbf{3}}\right)\end{array}$ \\
\hline 0.0 to 0.2 & 0.319 & 0.370 & 0.689 \\
\hline$>0.2$ to 0.616 & 0.319 & 0.370 & 0.689 \\
\hline$>0.616$ & 0.798 & 0.924 & 1.722 \\
\hline
\end{tabular}

Source: Zaragoza City Council (2005)

Table A3. Zaragoza water tariff (2006)

\begin{tabular}{|c|c|c|c|}
\hline $\begin{array}{c}\text { Consumption } \\
\left(\mathbf{m}^{\mathbf{3}} / \mathbf{d a y}\right)\end{array}$ & $\begin{array}{c}\text { Supply } \\
\left(\boldsymbol{€} / \mathbf{m}^{\mathbf{3}}\right)\end{array}$ & $\begin{array}{c}\text { Sewerage } \\
\left(\boldsymbol{€} / \mathbf{m}^{\mathbf{3}}\right)\end{array}$ & $\begin{array}{c}\text { Total } \\
\left(\boldsymbol{€} / \mathbf{m}^{\mathbf{3}}\right)\end{array}$ \\
\hline 0.0 to 0.2 & 0.379 & 0.389 & 0.768 \\
\hline$>0.2$ to 0.616 & 0.379 & 0.389 & 0.768 \\
\hline$>0.616$ & 0.948 & 0.972 & 1.920 \\
\hline
\end{tabular}

Source: Zaragoza City Council (2006) 


\section{Appendix II}

Table A4. Regressors: correlation matrix

\begin{tabular}{l|lllllllll} 
& $k l$ & pollut & product & msize & depth & distance park & price & summer \\
\hline KI & 1.0000 & & & & & & & & \\
Pollut & 0.0347 & 1.0000 & & & & & & & \\
product & -0.0637 & -0.0269 & 1.0000 & & & & & & \\
msize & 0.0514 & -0.0289 & -0.0605 & 1.0000 & & & & & \\
depth & 0.2230 & -0.0505 & -0.1243 & -0.0315 & 1.0000 & & & & \\
distance & 0.0933 & -0.0184 & -0.0449 & -0.2614 & 0.2951 & 1.0000 & & & \\
park & 0.1639 & -0.0133 & 0.0598 & -0.3429 & 0.3279 & 0.6012 & 1.0000 & & \\
price & -0.0205 & -0.0000 & -0.0000 & -0.0000 & -0.0000 & 0.0000 & 0.0000 & 1.0000 & \\
summer & 0.0000 & 0.0000 & -0.0000 & 0.0000 & -0.0000 & -0.0000 & -0.0000 & -0.0000 & 1.0000
\end{tabular}

